\title{
Model Hubungan Literasi, Pengalaman dan Perilaku Pengelolaan Keuangan Keluarga: Peran Niat Berperilaku Sebagai Mediasi
}

\author{
Anisa Mardianah ${ }^{1}, \mathbf{R r}$. Iramani ${ }^{2 *}$ \\ ${ }^{1,2 *)}$ Program Studi Manajemen, Universitas Hayam Wuruk Perbanas \\ Jl. Wonorejo Utara 16, Surabaya, Jawa Timur, Indonesia \\ Email: iramani@perbanas.ac.id ${ }^{2 *}$
}

\begin{abstract}
ABSTRAK
Pengelolaan keuangan keluarga sangat dibutuhkan dalam menumbuhkan ekonomi keluarga. Penelitian ini memiliki dua tujuan utama yaitu menguji pengaruh literasi keuangan dan financial experience pada perilaku pengelolaan keuangan keluarga, dan menguji peran behavioral intention dalam memediasi hubungan antara literasi dan pengelolaan keuangan. Penelitian ini melibatkan pengelola keuangan keluarga dengan menerapkan teknik purposive sampling dalam melaksanakan survei, dan selanjutnya data dianalisis menggunakan Partial Least Square (PLS). Hasil penelitian ini menunjukkan bahwa financial experience memiliki pengaruh positif signifikan terhadap perilaku pengelolaan keuangan. Temuan lain dari penelitian ini membuktikan bahwa literasi keuangan secara tidak langsung berpengaruh terhadap perilaku pengelolaan keuangan melalui peran mediasi penuh dari behavioral intention. Penelitian ini menawarkan implikasi managerial yang mana untuk meningkatkan pengelolaan keuangan dibutuhkan financial experience baik. Selain itu, penelitian ini menghasilkan wawasan baru bahwa seorang individu yang memiliki literasi keuangan tinggi harus juga memiliki behavioral intention keuangan yang baik agar pengelolaan keuangan keluarganya akan semakin cermat.
\end{abstract}

Kata kunci: Literasi Keuangan; Pengalaman Keuangan; Pengelolaan Keuangan; Niat Berperilaku

\begin{abstract}
Family financial management is necessary for the development of the family economy. The purpose of this study is to determine the effect of financial literacy and financial experience on family financial management behavior, as well as the role of behavioral intention in mediating the relationship between financial literacy and financial management behavior. The study surveyed family financial managers using a purposive sampling technique and then analyzed the data using Partial Least Squares (PLS). The findings of this study indicate that financial experience significantly improves financial management behavior. Additionally, this study's findings demonstrate that financial literacy indirectly affects financial management behavior via the full mediating role of behavioral intentions. This research offer managerial implications in which in improving an effective financial management requires financial experience. Furthermore, this research generates new insights that an individual with a high level of financial literacy must also intend to practice sound financial behavior to ensure his family's financial management accuracy.
\end{abstract}

Keyword: Financial Literacy; Financial Experience, Financial Management; Behavior Intention 


\section{PENDAHULUAN}

Pengelolaan keuangan keluarga merupakan cerminan dari perilaku individu dalam mengelola keuangan pribadi atau keuangan dalam keluarga agar tercipta tujuan keuangan keluarga yakni rasa aman dan sejahtera dalam keluarga. Masih manyak orang di sekitar kita yang belum mengetahui dan memahami bagaimana mengelola keuangan keluarga yang tepat. Hal ini sering terjadi pada keluarga yang menikah, dimana belum cermat dalam menyusun anggaran dan mengelola keuangan keluarga. Kekurang cermatan dalam mengelola keuangan keluarga akan mengakibatkan "besar pasak daripada tiang”. Kondisi tersebut kalau tidak segera disikapi akan berakibat fatal dimana keluarga tidak akan bebas financial. Biaya pendidikan dan kesehatan semakin meningkat dari waktu ke waktu, sehingga juga membutuhkan pengelolaan keuangan yang cermat. Individu yang sudah menikah didorong untuk lebih memperhatikan pengelolaan keuangan, karena keberlangsungan rumah tangga yang sejahtera bergantung pada pengelolaan rumah tangga yang cermat. Terdapat beberapa faktor yang mempengaruhi berhasil atau gagalnya pengelolaan keuangan rumah tangga dalam mencapai kesejahteraan secara financial dapat ditentukan oleh beberapa faktor, diantaranya adalah financial literacy (literasi keuangan), financial experience (pengalaman keuangan) serta behavioral intention (niat berperilaku)

Financial literacy adalah kemampuan untuk memahami konsep dasar bisnis dan keuangan serta menerapkannya secara tepat dan efektif. Seseorang dengan literasi keuangan yang baik akan pandai dalam mengelola keuangannya. Kemampuan individu atau keluarga untuk mengevaluasi dan membuat keputusan keuangan yang efektif mempengaruhi pengelolaan keuangan keluarga. Hasil studi Ida dan Dwinta (2010); Yulianti dan Silvy (2013), Mien dan Thao (2015); Brilianti dan Lutfi (2020); Iramani dan Lutfi (2021), menunjukkan bahwa financial literacy berpengaruh positif signifikan terhadap financial bahavior management. Hal ini dapat dijelaskan bahwa semakin tinggi financial literacy yang dimiliki individu, semakin baik dalam mengelola keuangannya.

Selain financial literacy, faktor yang menentukan baik buruknya pengelolaan keuangan adalah financial experience. Faktor ini juga sangat penting untuk keberlanjutan dalam mengelola keuangan keluarga. Financial experience dapat diartikan sebagai kejadian tentang suatu hal yang berhubungan dengan pengalaman individu dalam hal simpanan, pinjaman, investasi, catatan pembukuan, dan dana darurat (Yulianti dan Silvy, 2013). Lusardi dan Tufano (2009) menyatakan bahwa financial experience dapat mengurangi kebiasaan berhutang karena financial experience tersebut memberikan pengalaman mengenai kelemahan dari utang yang berlebih dan risiko dari keterlambatan pembayaran angsuran. Temuan 
Yulianti dan Silvy (2013); Brilianti dan Lutfi (2020); Iramani dan Lutfi (2021), membuktikan bahwa financial experience berdampak positif terhadap financial management behavior. Hal ini dapat dijelaskan bahwa individu yang memiliki financial experience yang baik, maka financial management behavior nya semakin cermat.

Behavioral intention dapat mempengaruhi pengelolaan keuangan dan dapat mencerminkan kemungkinan bahwa seseorang akan bertindak sesuai dengan perilakunya. Individu yang memiliki financial literacy yang baik akan mampu mengembangkan niat berperilaku positif, yang pada gilirannya dapat mengelola rumah tangga dengan baik dan bijaksana. Menurut Ajzen (1991), niat biasanya melibatkan usaha untuk menghindari preferensi jangka pendek supaya mencapai preferensi jangka panjang. Niat merupakan prediktor terbaik untuk melihat dinamika perilaku. Theory of planned behavior adalah niat individu dalam mengambil tindakan, karena niat sebagai variabel yang memediasi dampak financial literacy pada financial management behavior Behavioral intention dapat mengendalikan seseorang bertindak sesuai dengan perilakunya. Behavioral intention dalam mengelola keuangan adalah niat in untuk melakukan perencanaan keuangan, pengendalian atas pengeluaran, menyisihkan pendapatan untuk ditabung atau investasi masa depan. Survei Arganata dan Lutfi (2019) membuktikan bahwa behavioral intention berdampak positif terhadap pengelolaan keuangan keluarga.

Beberapa penelitian tentang perilaku pengelolaan keuangan telah dilakukan, namun pengembangan model perilaku keuangan dengan menguji behavioral intention sebagai mediasi variabel masih sangat terbatas. Pada penelitian sebelumnya yang telah dilakukan, dalam mengkaji pengaruh financial literacy dan atau financial experience terhadap financial management bahvior sebagian besar menggunakan teknik analisis regresi, dimana dengan teknik tersebut tidak dapat diketahui indikator yang kuat dan lemah dari setiap variabel. Penelitian ini bertujuan untuk menyempurnakan penelitian sebelumnya yang telah dilakukan baik dari model penelitiannya dan atau teknik analisis yang digunakan. Model dari penelitian sebelumnya hanya menguji pengaruh financial literacy terhadap financial behavior, sementara enelitian yang dilakukan saat ini memasukkan behavior intention sebagai variabel mediasi. Kebaruan lain dari penelitian ini adalah digunakannya PLS (Partial Least Square) sebagai analisis, sementara pada penelitian sebelumnya menggunakan Analisis Regresi Berganda. Dengan demikian diharapkan model yang ditemukan lebih komprehensif sehingga dapat memberikan kontrubusi pengembangan keilmuan pada riset behavioral finance.

Berdasarkan uraian sebelumnya, maka permasalahan dalam penelitian ini adalah apakah financial literacy dan financial experience berdampak pada financial management behavior 
serta apakah behavioral intention mampu memediasi financial literacy dalam mempengaruhi perilaku financial management behavior. Dengan demikian tujuan dari penelitian ini adalah menguji peran behavioral intention dalam memediasi pengaruh financial literacy terhadap perilaku financial management behavior.

Penelitian tentang literacy, intention dan financial behavior berdasarkan grand theory of planned behavior (TPB) yang dikemukakan oleh Ajzen (1991). Pendapat teori ini bahwa sikap dan kepercyaan seseorang akan berpengaruh pada perilaku seorang dalam menerima suatu keputusan atau justru menolaknya. Selain itu, teori ini juga mengungkapkan adanya hubungan antara literasi dengan niat individu dalam berperilaku. Perilaku pengelolaan keuangan merupakan cara mengelola dan mengendalikan keuangan serta aset yang dimiliki untuk secara produktif memenuhi semua kebutuhan hidup saat ini dan masa depan. Pengelolaan keuangan merupakan refleksi dari tanggung jawab seseorang dalam mengelola keuangan (Ida dan Dwinta, 2010). Sesorang yang mempunyai tanggung jawab finansial, cenderung mengelola keuangan dengan bai sehingga akan terhindar dari perilaku berkeinginan yang tanpa batas (Yulianti dan Silvy, 2013). Indikator perilaku pengelolaan keuangan meliputi: ketepatan pembayaran tagihan bulanan, penyisihan dana investasi, pengendalian pendapatan dan pengeluaran keuangan, penyisihan dana hari tua serta kecermatan dalam pengelolaan penghasilan bulanan.

Financial literacy adalah kemampuan seseorang dalam memahami konsep bisnis dan keuangan, sampai bagaimana mengaplikasikan dengan benar dan efektif. Menurut Ida dan Dwinta (2010), financial literacy adalah suatu keputusan yang cermat tentang bagaimana mengelolan kas keluar dan investasi dari dana yang dimiliki untuk meningkatkan aset dimasa mendatang Sementara Panggabean dan Dalmonte (2018); Arianti dan Azzahra (2020) mengemukakan bahwa financial literacy dapat dilihat dari sikap dan perilaku dalam merencanakan investasi, tabungan, dan konsumsi dalam mengelola keuangan.

Chen dan Volpe (1998), menyatakan bahwa financial literacy merupakan pengetahuan untuk mengelola keuangan sebagai pedoman dalam menentukan keputusan keuangan. Financial literacy dapat diukur dengan menggunakan indikator: pengetahuan tentang keuangan dasar, perbankan, investasi serta pengetahuan tentang asuransi dan dana pensiun. Financial literacy yang baik akan berdampak positif pada financial management behavior. Temuan survei yang dilakukan Ida dan Dwinta (2010) memberikan bukti bahwa financial literacy berpengaruh positif signifikan terhadap financial management behavior. Chen dan Volpe (1998) menyatakan bahwa tingginya financial literacy yang dimiliki seseorang berdampak pada financial management behaviornya serta bijak dalan memanfaatkan produk 
dan instrumen keuangan. Hasil ini selaras dengan hasil penelitian Ida dan Dwinta (2010); Yulianti dan Silvy (2013), Mien dan Thao (2015); Brilianti dan Lutfi (2020); Iramani dan Lutfi (2021), yang menemukan bukti bahwa financial literacy berdampak positif signifikan pada financial management behavior. Berdasarkan kajian empiris dari studi yang dilakukan peneliti sebelumnya, maka hipotesis penelitian yang akan diuji adalah:

\section{H1: Financial literacy berpengaruh positif signifikan terhadap financial management behavior}

Seorang individu atau pengelola keuangan keluarga yang mempunyai financial literay yang tinggi, berarti individu tersebut dapat memahami konsep dasar bisnis dan keuangan serta mampu menerapkan dengan tepat dan efektif. Semakin tinggi financial literacy individu tersebut maka akan mampu mempengaruhi behavioral intention. Jika seseorang memiliki niat yang kuat untuk menabung secara teratur baik untuk diri sendiri maupun keluarganya dan berivestasi untuk stabilitas keuangan di hari tua, maka individu akan merealisasikan niat tersebut dengan cara menyisihkan pendapatannya untuk ditabung atau diinvestasikan sebagai jaminan keuangan di hari tuanya.Indikator behavior intention meliputi: niat untuk membayar tagihan bulanan tepat waktu, niat berbelanja tanpa kartu kredit, niat memenuhi kebutuhan operasional tanpa hutang, niat tidak menggunakan tabungan atau menjual investasi untuk kebutuhan sehari-hari. Menurut teori Ajzen (1991), behavior intention adalah prediktor kuat untuk perilaku. Studi Arganata dan Lutfi (2019) membuktikan bahwa behavioral intention berpengaruh positif terhadap financial management behavior keluarga. Ketika seseorang memiliki niat baik dalam mengelola keuangan, niat tersebut akan memotivasi individu untuk mengendalikan diri dan keuangannya secara serius. Theory of planned behavior menyatakan bahwa penentu terpenting perilaku seseorang adalah intention (niat) untuk berperilaku. Hal ini berarti bahwa niat digunakan sebagai pemediasi financial literacy terhadap financia; management behavior Ketika seseorang memiliki financial literacy yang baik dan terbentuk niat perilaku yang positif, maka niat tersebut dapat direalisasikan mengelola keuangan keluarga dengan baik dan bijak. Oleh karena itu, dari financial literacy maka timbullah niat untuk mengelola keuangan dengan baik, yang nantinya akan berdampak signifikan terhadap perilaku pengelolaan keuangan seperti perencanaan, penganggaran, pengelolaan, penyisihan dana keluarga. Dari sini dapat disimpulkan bahwa behavioral intention mampu memediasi dampak financial literay terhadap financial management behavior keluarga. Oleh karena itu hipotesis penelitian yang diuji adalah: 


\section{H2: Behavioral intention mampu memediasi pengaruh financial literacy terhadap} financial management behavior

Financial experience adalah peristiwa keuangan yang pernah dialami seseorang sebelumnya, baik itu lama atau baru (Yulianti dan Silvy, 2013). Financial experience merupakan hal yang sangat penting yang diperlukan untuk keberlanjutan hidup dimasa mendatang utamanya bagi individu yang sudah berkeluarga. Menurut Lusardi dan Tufano (2009) financial experience memberikan pembelajaran tentang risiko dari hutang yang brelebihan dan risiko keterlambatan pembayaran tagihan. Oleh karena itu perilaku hutang semestinya diminimalisir. Financial experience dapat diukur dengan menggunakan indikator sebagai berikut: pengalaman dalam membuka rekening deposito, pengalaman dalam melakukan investasi saham, pengalaman investasi reksadana, pengalaman dalam menggadaikan asset, pengalaman investasi logam mulia, pengalaman dalam pembayaran premi asuransi serta pengalaman dalam program dana pensiun. Jika seorang individu memiliki financial experience yang tinggi maka invidu tersebut akan memdapat pembelajaran dari pengalamannya dengan lebih baik dan penilaian terhadap pengalaman keuangan yang telah terjadi dapat dilakukan. Jika seseorang memiliki sedikit financial experience, maka individu tersebut akan kurang mampu dalam mengelola keuangannya

Menurut Lusardi dan Tufano (2009), individu dengan financial experience lebih baik, akan berhutang sesuai dengan kemampuan dalam membayar tagihan tepat waktu. Hasil penelitian Yulianti dan Silvy (2013); Purwidianti dan Mudjiyanti (2016); Brilianti dan Lutfi (2020); Iramani dan Lutfi (2021), berhasil memberikan bukti empiris bahwa financial experience berpengaruh positif siginifikan terhadap financial management behavior. Atas dasar kajian empiris dari penelitian sebelumnya, hipotesis penelitian terakhir dirumuskan sebagai berikut:

H3: Financial experience berpengaruh positif signifikan terhadap financial management behavior

Dari bukti empiris yang ditemukan peneliti sebelumnya serta hipotesis penelitian yang telah dirumuskan, maka kerangka konseptual dapat digambarkan sebagai berikut: 


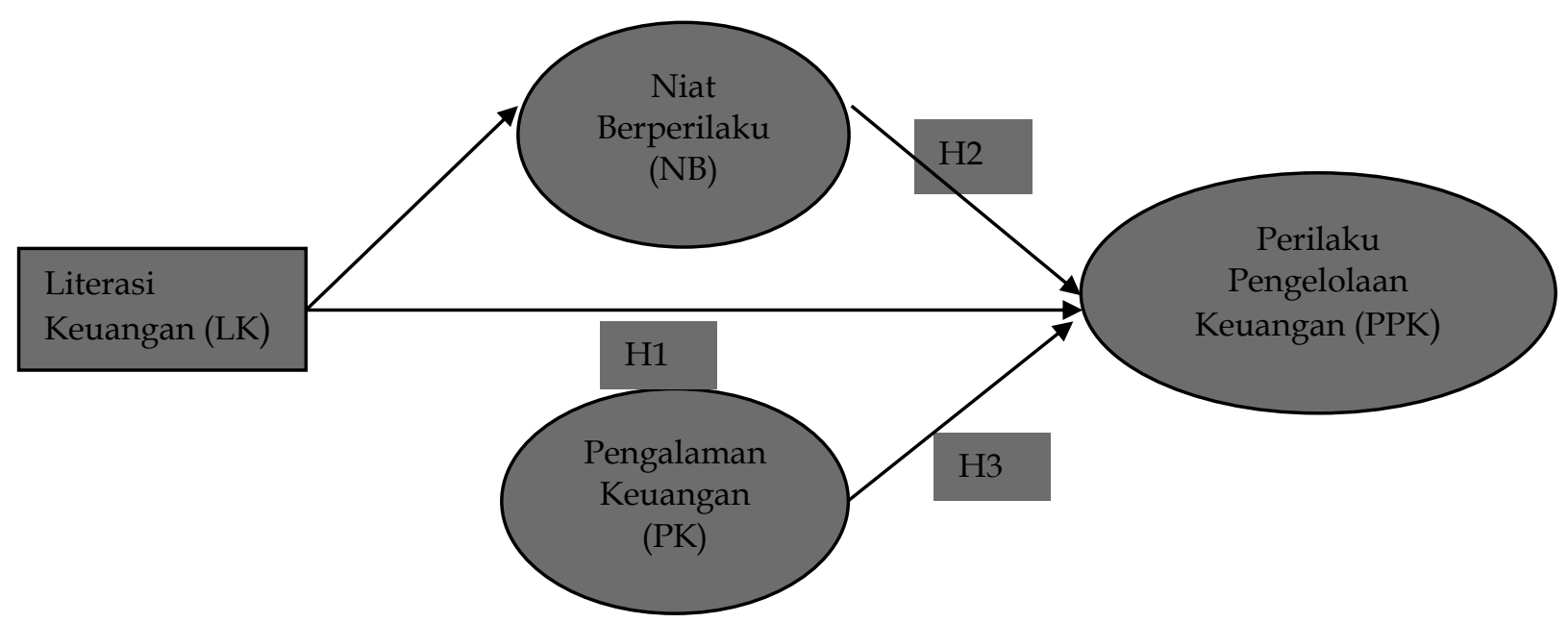

Gambar 1. Kerangka Konseptual Penelitian

\section{METODE PENELITIAN}

Studi yang dilakukan saat ini mempunyai tujuan untuk menguji pengaruh financial literay dan financial experience terhadap financial management behavior. Penelitian ini dilakukan di Surabaya, Gresik dan Lamongan dimana ketiga kota tersebut merupakan bagian dari wilayah Gerbangkertasusila. Purposive sampling adalah metede sampling yang digunakan dalam penelitian ini. Kriteria sampel yang dipilih dalam dalam penelitian ini adalah pengelola keuangan yang sudah berkeluarga dengan total penghasilan per bulan minimal empat juta rupiah. Data yang dikumpulkan bersumber pada data primer yang diperoleh langsung dari responden terpilih. Metode survei digunakan dalam penelitian ini untuk mengunmpulkan data dengan cara menyebarkan kuesioner yang memuat pertanyaan tentang profil responden dan pertanyaan/pernyataan yang terkait dengan variabel yang diteliti. Terdapat 545 kuesioner yang terkumpul dan dianalisis.

Variabel yang diteliti dalam penelitian ini meliputi: financial management behavior sebagai dependent variable, financial literacy dan financial experience sebagai independent variable serta behavioral intention sebagai intervening variable atau variabel mediasi. Pengukuran variabel perilaku pengelolaan keuangan dengan menggunakan skala likert, dengan pilihan jawaban: "tidak pernah" diberi skor "1" sampai jawaban "selalu" dengan skor "5". Variabel behavioral intention juga diukur dengan skala likert, dengan pilihan jawaban: "sangat tidak setuju" yang diberi skor "1" sampai jawaban "sangat setuju" dengan skor "5".

Untuk variabel financial literacy diukur dengan menggunakan skala rasio dengan rumus:

$$
\text { Financial literacy }=\frac{\sum \text { jawaban benar }}{\sum \text { pertanyaan }} \times 100 \% \text {. }
$$

Skor financial literacy dikategorikan rendah jika kurang dari 60 persen, sedang jika terletak 
antara 60-80 persen dan tinggi jika lebih dari 80 persen (Chen dan Volpe , 1998),

Variabel financial experience juga diukur dengan menggunakan skala rasio dengan rumus:

$$
\text { Financial experience }=\frac{\sum \text { jawaban " } \mathrm{Ya}^{\mathrm{I}}}{\sum \text { pertanyaan }} \times 100 \%
$$

Variabel yang diteliti tersebut dituangkan dalam kuesioner yang digunakan sebagai instrumen penelitian. Adapun kisi-kisi kuesioner disajikan pada Tabel 1.

Tabel 1. Kisi-kisi Kuesioner

\begin{tabular}{|c|c|c|}
\hline $\begin{array}{l}\text { Variabel } \\
\text { penelitian }\end{array}$ & Indikator & Item \\
\hline Identitas & $\begin{array}{l}\text { Nama } \\
\text { Alamat } \\
\text { Jenis kelamin } \\
\text { Usia } \\
\text { Total penghasilan per bulan } \\
\text { Sebagai pengelola keuangan keluarga }\end{array}$ & $\begin{array}{l}: \\
: \\
: \mathrm{L} / \mathrm{P} \\
: \\
:\end{array}$ \\
\hline $\begin{array}{l}\text { Financial } \\
\text { management } \\
\text { behavior }(\mathrm{Y})\end{array}$ & $\begin{array}{l}\text { 1. Ketepatan pembayaran tagihan bulanan } \\
\text { 2. Penyisihan dana untuk menabung atau berinvestasi. } \\
\text { 3. Pengendalaian pendapatan dan pengeluaran keluarga. } \\
\text { 4. Penyisihan dana hari tua. } \\
\text { 5. Kedisiplinan pengelolaan penghasilan bulanan }\end{array}$ & $\begin{array}{l}\text { P a / 1 1dak } \\
\text { PPK } 1 \\
\text { PPK } 2 \\
\text { PPK } 3 \\
\text { PPK } 4 \\
\text { PPK } 5\end{array}$ \\
\hline $\begin{array}{l}\text { Financial } \\
\text { literacy }\left(\mathrm{X}_{1}\right)\end{array}$ & $\begin{array}{l}\text { 1. Pengetahuan keuangan dasar } \\
\text { 2. Pengetahuan perbankan } \\
\text { 3. Pengetahuan investasi } \\
\text { 4. Pengetahuan asuransi }\end{array}$ & $\begin{array}{l}\text { LK } 1-2 \\
\text { LK 3-4 } \\
\text { LK } 5-8 \\
\text { LK } 9\end{array}$ \\
\hline $\begin{array}{l}\text { Financial } \\
\text { experience }\left(\mathrm{X}_{2}\right)\end{array}$ & $\begin{array}{l}\text { 1. Financial experience terkait produk perbankan } \\
\text { 2. Financial experience terkait pasar modal } \\
\text { 3. Financial experience terkait produk pegadaian } \\
\text { 4. Financial experience terkait produk asuransi } \\
\text { 5. Financial experience terkait produk dana pensiun }\end{array}$ & $\begin{array}{l}\text { PK } 1 \\
\text { PK } 2-3 \\
\text { PK } 4-5 \\
\text { PK } 6 \\
\text { PK } 7-8\end{array}$ \\
\hline $\begin{array}{l}\text { Behavioral } \\
\text { intention } \\
\text { (mediasi) }\end{array}$ & $\begin{array}{l}\text { 1. Niat pembayaran tagihan bulanan tepat waktu } \\
\text { 2. Niat berbelanja tanpa kartu kredit } \\
\text { 3. Niat memenuhi kebutuhan operasional tanpa menggunakan hutang } \\
\text { 4. Niat tidak menggunakan tabungan atau menjual investasi untuk } \\
\text { oprasional sehari-hari. }\end{array}$ & $\begin{array}{l}\text { NB } 1 \\
\text { NB } 2 \\
\text { NB } 3 \\
\text { NB } 4\end{array}$ \\
\hline
\end{tabular}

Sumber : Arganata dan Lutfi (2019), Chen dan Volpe (2016), Purwidianti dan Mudjiyanti (2016)

Dalam menganalisis data dalam penelitian ini menggunkaan analisis deskriptif dan analisis inferensial. Analisis deskriptif digunakan untuk memberikan gambaran tentang indikator serta variabel yang diteliti dengan menggunakan nilai statistic mean, minimum dan maksimum. Analisis inferensial digunakan untuk menguji hipotesis yang telah dirumuskan. Adapun analisis inferensial yang digunakan adalah Partial Least Square (PLS). Teknik ini mempunyai keuanggulan yakni dapat menguji pengaruh literasi dan financial experience sebagai variabel bebas serta behavioral intention sebagai variabel mediasi secara simultan terhadap financial management behavior. Selain itu, keunggulan PLS adalah dapat 
menentukan indikator yang terkuat dalam mengukur variabel penelitian. Adapun langkahlangkah analisisnya adalah: uji outer model digunakan untuk menguji validitas dan reliabilitas; uji inner model digunakan untuk menguji apakah model fit atau tidak; pengujian hipotesis digunakan untuk menguji apakah financial literacy, financial experience berpengaruh terhadap financial management behavior serta menguji peran behavioral intention sebagai mediasi pengaruh financial literacy erhadap financial magement behavior. Hipotesis yang diajukan dalam penelitianini diterima jika $\mathrm{P}_{\text {value }}<0,05$

\section{HASIL DAN PEMBAHASAN}

Penelitian ini bertujuan untuk mengkaji pola hubungan financial literacy, financial experience dan perilaku pengelolaab keuangan serta peran behavioral intention sebagai mediasi. Sebelum dilakukan pengujian, akan dijelaskan deskripsi dari masing-masing variabel penelitian. Topik penelitian ini adalah perilaku pengelolaan keuangan, yakni perilaku individu dalam mengelola serta mengendalikan keuangan dan asset yang dimiliki untuk memenuhi kebutuhan hidup saat ini dan dimasa yang akan mendatang. Variabel ini diukur dengan skala likert dengan pilihan jawaban "tidak pernah" sampai "selalu". Tanggapan responden untuk variabel tersebut disajikan pada Tabel 2.

Tabel 2. Statistik Deskriptif Variabel Perilaku Pengelolaan Keuangan

\begin{tabular}{|c|c|c|c|c|c|c|c|}
\hline \multirow[b]{2}{*}{ Item } & \multirow[b]{2}{*}{ Indikator } & \multicolumn{5}{|c|}{ Jawaban Responden (\%) } & \multirow{2}{*}{$\begin{array}{l}\text { Rata2 } \\
\text { Skor } \\
\text { Indikator } \\
\end{array}$} \\
\hline & & $\mathbf{T P}$ & KK & $\mathbf{S}$ & SS & SL & \\
\hline PPK 1 & $\begin{array}{l}\text { Ketepatan pembayaran tagihan bulanan } \\
\text { Penyisihan dana untuk tabungan atau }\end{array}$ & 0,00 & 0,92 & 7,34 & 36,70 & 55,05 & 4,46 \\
\hline PPK 2 & investasi. & 0,92 & 3,67 & 9,17 & 29,36 & 56,88 & 4,38 \\
\hline PPK 3 & Pengendalaian cash flow keluarga & 3,67 & 1,83 & 12,84 & 33,03 & 48,62 & 4,21 \\
\hline PPK 4 & $\begin{array}{l}\text { Penyisihan dana hari tua } \\
\text { Kedisiplinan pengelolaan penghasilan }\end{array}$ & 0,00 & 3,67 & 7,34 & 28,44 & 60,55 & 4,46 \\
\hline PPK 5 & bulanan & 0,92 & 2,75 & 13,76 & 33,94 & 48,62 & 4,27 \\
\hline
\end{tabular}

Sumber: hasil survei 2021, data diolah

Keterangan: TP=tidak pernah; KK=kadang-kadang; $\mathrm{S}=$ sering; $\mathrm{SS}=$ sangat sering; $\mathrm{SL}=$ selalu

Berdasarkan Tabel 2 terlihat bahwa rata-rata skor tertinggi adalah item PPK 4,46 yakni indikator penyisihan dana hari tua dan terrendah PPK 3 yaitu indikator cash flow keluarga. Rata-rata skor variabel sebesar 4,36. Hal ini dapat dijelaskan bahwa perilaku pengelolaan responden sangat baik.

Variabel berikutnya yang akan dilakukan analisis deskriptif adalah financial literacy dan financial experience yang bertindak sebagai variabel bebas dalam model penelitian yang akan diuji. Hasil nya disajikan pada Tabel 3 dan Tabel 4. 
Tabel 3. Statistik Deskriptif Financial Literacy

\begin{tabular}{|c|c|c|c|c|}
\hline Indikator & $\begin{array}{l}\text { No. } \\
\text { Item }\end{array}$ & Pertanyaan & Skor Item & $\begin{array}{l}\text { Rata-Rata } \\
\text { Indikator }\end{array}$ \\
\hline \multirow{2}{*}{$\begin{array}{l}\text { Pengetahuan } \\
\text { Keuangan Dasar }\end{array}$} & LK1 & Pengertian inflasi meningkat & 32,07 & \multirow{2}{*}{40,35} \\
\hline & LK2 & Pengertian kekayaan bersih & 48,62 & \\
\hline \multirow{2}{*}{$\begin{array}{l}\text { Pengetahuan } \\
\text { Perbankan }\end{array}$} & LK3 & Tingkat suku bunga & 22,94 & \multirow{2}{*}{44,96} \\
\hline & LK4 & Kredit modal kerja & 66,97 & \\
\hline \multirow{4}{*}{$\begin{array}{l}\text { Pengetahuan } \\
\text { investasi }\end{array}$} & LK5 & Investasi jangka panjang & 59,63 & \\
\hline & LK6 & Pengertian reksadana & 37,61 & \multirow{3}{*}{47,48} \\
\hline & LK7 & Teknik investasi & 44,04 & \\
\hline & LK8 & Dividen saham & 48,62 & \\
\hline \multirow{3}{*}{$\begin{array}{l}\text { Pengetahuan } \\
\text { asuransi dan dana } \\
\text { pensiun }\end{array}$} & LK9 & Manfaat asuransi & 58,72 & \multirow{3}{*}{59,50} \\
\hline & LK10 & Manfaat dana pensiun & 60,28 & \\
\hline & & Rata-rata skor Financial lit & & \\
\hline
\end{tabular}

Sumber: hasil survei 2021, data diolah

Tabel 3 menunjukkan bahwa rata-rata financial literacy responden 48,02 persen Skor financial literacy tersebut termasuk dalam kategori rendah (Chen and Volpe, 1998). Skor literasi tertinggi pada pengetahuan asuransi dan dana pensiun, sedangkan yang terrendah pada pengetahuan keuangan dasar. Mayoritas responden belum memahami makna inflasi dan arti kekayaan bersih pada keluarga.

Tabel 4. Statistik Deskriptif Financial Experience

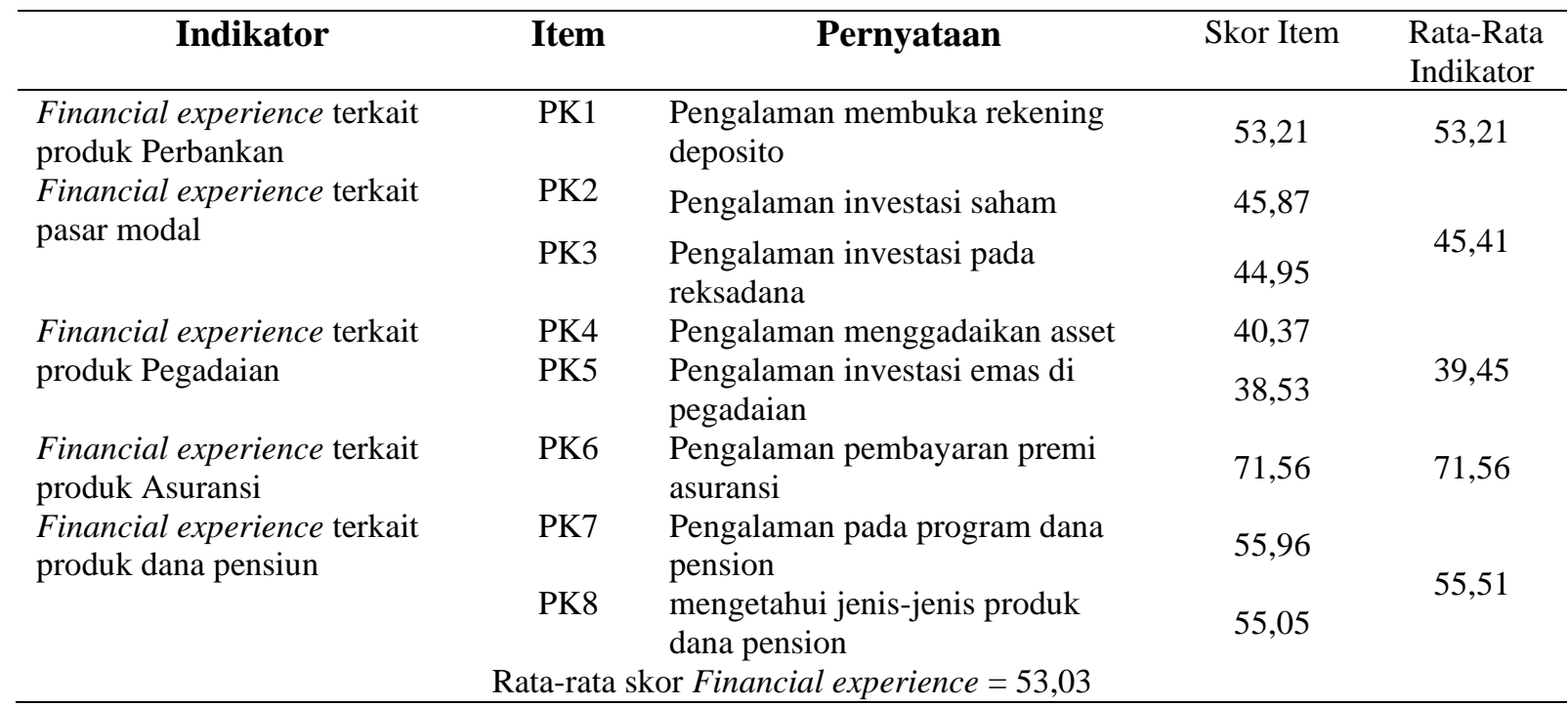

Sumber: hasil survei 2021, data diolah

Dari Tabel 4, diketahui bahwa skor terrendah terletak pada indikator financial experience terkait produk pegadaian, sementara skor tertinggi pada indikator financial experience terkait produk dana pension. Secara keseluruhan rata-rata skor financial experience 53,03 lebih tinggi dibanding skor financial literacy sebesar 48,02. 
Variabel terakhir yang akan dideskripsikan adalah variabel niat berperilaku yang bertindak sebagai variabel mediasi, yang disajikan pada Tabel 5.

Tabel 5. Statistik Deskriptif Variabel Behavioral intention

\begin{tabular}{|c|c|c|c|c|c|c|c|}
\hline \multirow{2}{*}{ Item } & \multirow{2}{*}{ Indikator } & \multicolumn{5}{|c|}{ Jawaban Responden (\%) } & \multirow{2}{*}{$\begin{array}{c}\text { Rata2 } \\
\text { Skor } \\
\text { Indikator }\end{array}$} \\
\hline & & STS & TS & KS & S & SS & \\
\hline NB 1 & Niat pembayaran tagihan bulanan tepat waktu & 0,00 & 1,83 & 5,50 & 32,11 & 60,55 & 4,51 \\
\hline NB 2 & Niat berbelanja tanpa kartu kredit & 0,92 & 4,59 & 9,17 & 36,70 & 48,62 & 4,28 \\
\hline NB 3 & $\begin{array}{l}\text { Niat memenuhi kebutuhan operasional bulan } \\
\text { tanpa hutang }\end{array}$ & 1,83 & 4,59 & 6,42 & 33,03 & 54,13 & 4,33 \\
\hline NB 4 & $\begin{array}{l}\text { Niat tidak menggunakan tabungan atau } \\
\text { menjual investasi untuk operasional sehari-hari }\end{array}$ & 0,92 & 1,83 & 11,93 & 33,03 & 52,29 & 4,34 \\
\hline
\end{tabular}

Sumber: hasil survei 2021, data diolah

Keterangan: STS = sangat tidak setuju; TS=tidak setuju; KS=kurang setuju; $S=$ setuju; $S S=$ sangat setuju

Berdasarkan Tabel 5, dapat diketahui rata-rata skor tertinggi adalah item NB1 yakni indikator niat pembayaran tagihan tepat waktu, dan terrendah NB2 yaitu indikator niat berbelanja bulan depan dengan tidak menggunakan kartu kredit. Hal ini dapat dijelaskan bahwa responden hanya menggunakan kartu kredit untuk kebutuhan darurat, bukan untuk operasional. Rata-rata skor variabel behavioral intention sebesar 4,37. Hal ini dapat dijelaskan bahwa behavioral intention keuangan responden sangat baik.

Analisis selanjutnya adalah PLS. Tahap pertama yang dilakukan dalam analsii PLS adalah uji outer model, yakni menguji validitas dan reliabilitas data penelitian. Ringkasan hasil pengujian disajikan pada Tabel 6.

Tabel 6. Ringkasan Hasil Uji Validitas dan Reliabilitas

\begin{tabular}{|c|c|c|c|c|c|c|c|}
\hline Variabel & Item & $\begin{array}{l}\text { Loading } \\
\text { Factor }\end{array}$ & Kesimpulan & P-Value & $\begin{array}{l}\text { Composite } \\
\text { Reliability }\end{array}$ & $\begin{array}{l}\text { Crobanch } \\
\text { Alpha }\end{array}$ & Kesimpulan \\
\hline \multirow{5}{*}{$\begin{array}{l}\text { Financial } \\
\text { management } \\
\text { behavior }\end{array}$} & PPK 1 & $(0,755)$ & Valid & $<0,001$ & \multirow{5}{*}{0,875} & \multirow{5}{*}{0,821} & \multirow{5}{*}{ Reliabel } \\
\hline & PPK 2 & $(0,811)$ & Valid & $<0,001$ & & & \\
\hline & PPK 3 & $(0,799)$ & Valid & $<0,001$ & & & \\
\hline & PPK 4 & $(0,761)$ & Valid & $<0,001$ & & & \\
\hline & PPK 5 & $(0,700)$ & Valid & $<0,001$ & & & \\
\hline \multirow{4}{*}{$\begin{array}{l}\text { Behavioral } \\
\text { intention }\end{array}$} & NB 1 & $(0,703)$ & Valid & $<0,001$ & \multirow{4}{*}{0,822} & \multirow{4}{*}{0,710} & \multirow{4}{*}{ Reliabel } \\
\hline & NB 2 & $(0,774)$ & Valid & $<0,001$ & & & \\
\hline & NB 3 & $(0,791)$ & Valid & $<0,001$ & & & \\
\hline & NB 4 & $(0,752)$ & Valid & $<0,001$ & & & \\
\hline \multirow{2}{*}{$\begin{array}{l}\text { Financial } \\
\text { literacy } \\
\text { Financial } \\
\text { experience }\end{array}$} & LK1-LK 12 & & Tidak Diuji & & \multicolumn{3}{|c|}{ Tidak diuji } \\
\hline & PK 2-9 & & Tidak Diuji & & & Tidak diuji & \\
\hline
\end{tabular}

Sumber: hasil survei, data diolah

Berdasarkan Tabel 6 dapat dijelaskan bahwa semua indikator yang mengukur variabel perilaku peneglolaan serta behavioral intention terbukti valid (nilai loading factor > 0,70 dengan $\mathrm{p}_{\mathrm{value}}<0,05$ ) dan reliabel (nilai Cronbach alpha $>0,6$ ). Untuk variabel literasi dan financial experience tidak diuji validitas dan reliabilitas karena pengukuran variabel ini 
dengan menggunakan skala rasio. Selanjutnya, akan dilakukan uji inner model serta uji hipotesis. Ringkasan hasilnya disajikan pada Tabel 7 dan Gambar 1.

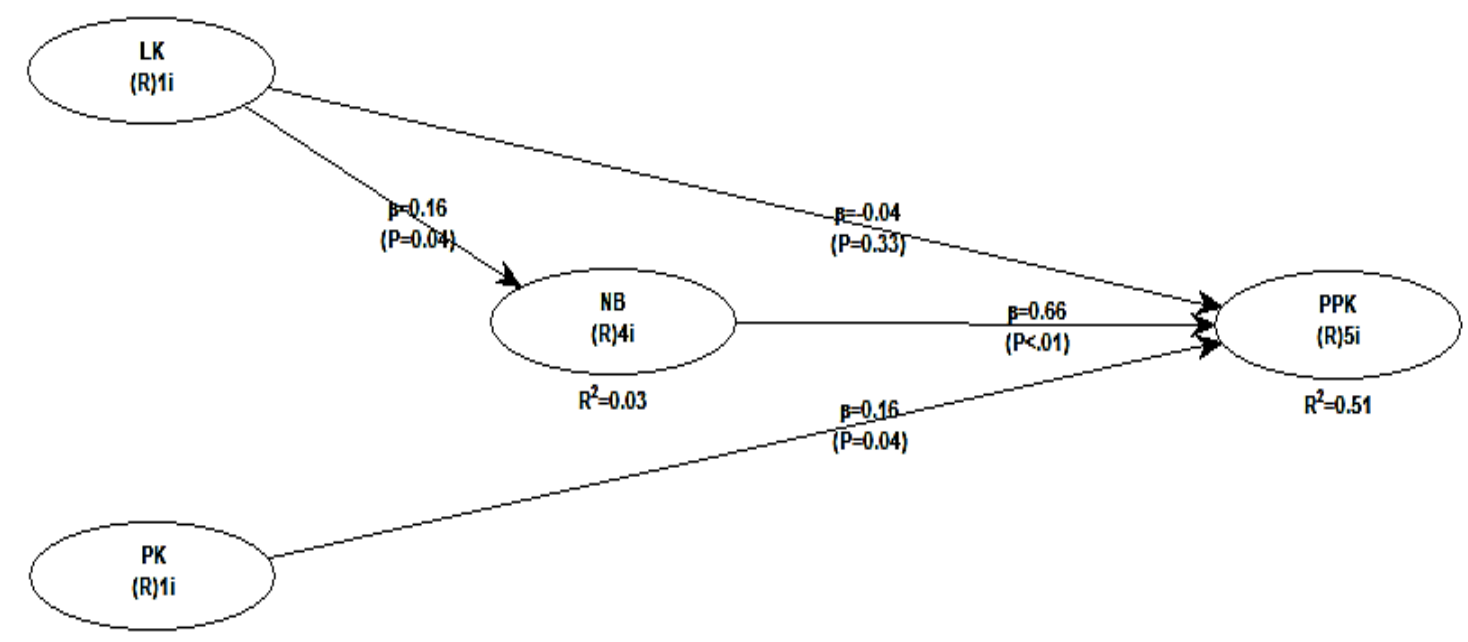

Gambar 2. Pola Hubungan Variabel

Tabel 7. Ringkasan hasil Uji Hipotesis

\begin{tabular}{ccccc}
\hline Hipotesis & Hubungan Variabel & Nilai koefisen $\boldsymbol{\beta}$ & P-Value & Hasil Pengujian \\
\hline $\mathrm{H} 1$ & $\mathrm{LK} \rightarrow \mathrm{PPK}$ & $-0,04$ & 0,33 & H1 ditolak \\
$\mathrm{H} 2$ & $\mathrm{LK} \rightarrow \mathrm{NB}$ & 0,16 & 0,04 & $\mathrm{H} 2$ diterima \\
& $\mathrm{NB} \rightarrow \mathrm{PPK}$ & 0,66 & $<0,01$ & \\
$\mathrm{H} 3$ & $\mathrm{PK} \rightarrow \mathrm{PPK}$ & 0,16 & 0,04 & $\mathrm{H} 3$ diterima \\
& & Nilai $R$-Square $\left(\mathrm{R}^{2}\right)=0,51$ & &
\end{tabular}

Sumber: hasil survei 2021, data diolah

Keterangan: LK=Financial literacy; $\mathrm{PK}=$ Financial experience $; \mathrm{NB}=$ Behavioral intention $; \mathrm{PPK}=$ Financial management behavior

Berdasarkan Tabel 7 dan Gambar 1 dapat diketahui model yang terbentuk memiliki nilai $\mathrm{R}^{2}=0,51$ artinya 51 persen variasi pada financial management behavior dapat dijelaskan oleh financial literacy, financial experience serta behavioral intention. Dengan demikian 49 persen sisanya dijelaskan variabel lain diluar model. Dengan demikian model yang ditemukan dalam kategori moderat. Selanjutnya, diperoleh hasil financial literacy tidak berpengaruh terhadap financial management behavior, yang ditunjukkan oleh $\mathrm{P}_{\text {value }}=0,33$ lebih besar dari 0,05. Dengan demikian hipotesis pertama dalam penelitian ini tidak berhasil diterima atau tidak ditemukan bukti bahwa financial literacy berdampak pada financial management behavior. Hal ini dapat dijelaskan bahwa tinggi rendahnya financial literacy pengelola keuangan dalam keluarga tidak memberikan dampak pada baik buruknya financial management behavior. 
Bukti empiris diatas relevan dengan penelitian Kholilah dan Iramani (2013) serta Arganata dan Lutfi (2019) yang menemukan bukti bahwa financial literacy tidak berpengaruh terhadap financial management behavior. Hasil pengujian tersebut ini tidak selaras dengan penelitian Ida dan Dwinta (2010); Yulianti dan Silvy (2013) Mien dan Thao (2015); Brilianti dan Lutfi (2020); serta Iramani dan Lutfi (2021), yang membuktikan bahwa financial literacy berpengaruh positif signifikan terhadap financial management behavior. Tidak ditemukannya pengaruh financial literacy terhadap financial management behavior ini dapat terjadi karena terdapat responden yang literasinya tinggi namun perilaku pengelolaan keuangannya baik, sebaliknya responden yang financial literacynya tinggi, financial management behaviornya tidak baik. Dari hasil analisis deskriptif diperoleh hasil bahwa financial literacy responden masih tergolong rendah, yakni 48,02 persen

Financial literacy terbukti berpengaruh positif signifikan terhadap behavioral intention $\left(\mathrm{p}_{\mathrm{value}}=0,04\right)$ dan behavioral intention juga terbukti berpengaruh positif signifikan terhadap perilaku pengelolaan $\left(\mathrm{p}_{\text {value }}<0,01\right)$, namun financial literacy secara langsung tidak terbukti mempengaruhi financial management behavior. Hal ini menunjukkan bahwa financial literacy berpengaruh tidak langsung terhadap financial management behavior, namun harus dimediasi oleh behavioral intention. Hasil ini dapat dijelaskan bahwa behavioral intention mampu memediasi secara penuh (full mediation) pengaruh financial literacy terhadap financial management behavior. Dengan demikian hipotesis kedua dalam penelitian ini secara empiris terbukti.

Financial literacy secara tidak langsung dapat mempengaruhi financial management behavior melalui variabel behavioral intention sebagai variabel mediasi. Jika seseorang memiliki niat, maka niat tersebut dapat diterjemahkan ke dalam tindakan. Oleh karena itu, jika seseorang memiliki financial literacy yang tinggi dan niat yang baik, maka financial management behaviornya juga baik. Nilai rata-rata persepsi responden untuk variabel niat sebesar 4,37 yang artinya bahwa responden memiliki niat yang sangat tinggi dalam melakukan pengelolaan keuangan. Responden sangat berhati-hati dalam mengelola keuangannya. Salah satu caranya adalah membayar tagihan tepat waktu untuk menghindari masalah keterlambatan pembayaran tagihan. Selain itu, responden berniat untuk membelanjakan uang tanpa kartu kredit atau utang. Responden akan selalu mencatat pengeluaran yang dilakukan untuk meminimalkan pengeluaran yang berlebihan. Hal ini menunjukkan bahwa responden berniat mengelola keuangannya dengan sangat baik.

Hasil pengujian hipotesis ini memperkuat hasil studi Arganata dan Lutfi (2019) yang membuktikan bahwa behavioral intention berpengaruh positif terhadap financial management 
Temuan ini mendukung teori Ajzen (1991) yang menjelaskan bahwa niat merupakan prediktor kuat untuk perilaku. Ketika seseorang memiliki niat baik untuk mengelola keuangan, niat tersebut akan memotivasinya untuk mengendalikan diri dan keuangannya secara serius. Dari teori tersebut, dapat dijelaskan bahwa faktor utama dalam perilaku sesorang adalah intention (niat) untuk berperilaku. Hal ini dapat diartikan bahwa niat memediasi financial literacy terhadap financial management behavior. Ketika individu mempunyai financial literacy yang baik maka akan membentuk behavioral intention yang bersifat positif, sehingga dari terbentuknya literacy maka akan muncul niat untuk mengelola keuangan keluarga dengan baik yang nantinya individu tersebut bertindak secara riil pada financial management behavior seperti selalu menyisihkan pendapatannya secara berkala untuk tabungan dan investasi, membuat anggaran dengan baik.

Hipotesis ketiga dalam penelitian ini menyatakan bahwa financial experience berpengaruh positif signifikan terhadap financial management behavior. Berdasarkan Tabel 3 dan Gambar 1, diketahui bahwa koefesien path dari financial experience $\beta=0,16$ dengan $p_{\text {value }}=0,04$. Dengan demikian hipotesis ketiga berhasil dibuktikan. Hal ini dapat dijelaskan bahwa semakin baik financial experience maka semakin cermat individu dalam mengelola keuangannya. Individu yang memiliki pengalaman dalam hal asuransi misalnya, akan dapat meminimalisir dan melindungi asset dan investasinya sehingga terhindar dari risiko kerugian. Individu yang berpengalaman dalam hal dana pensiun akan menyisihkan penghasilannya untuk hari tua. Temuan ini mendukung hasil penelitian Brilianti dan Lutfi (2020); Yulianti dan Silvy (2013) yang membuktikan bahwa financial experience mempunyai dampak positif terhadap financial management behavior.

\section{KESIMPULAN DAN SARAN}

Berdasarkan analisis data yang telah dilakukan dapat disimpulkan: financial experience yang baik akan meningkatkan financial management behavior individu. Implikasi hasil ini adalah untuk meningkatkan pengelolaan keuangan dibutuhkan financial experience baik. Simpulan lain dari penelitian ini adalah financial literacy yang tinggi belum tentu dapat meningkatkan financial management behavior, jika tidak diikuti dengan behavioral intention yang baik. Dengan demikian temuan baru yang memberikan kontribusi dalam pengembangan model financial management behavior adalah kemampuan behavioral intention sebagai mediasi hubungan antara financial literacy dan financial management behavior. Simpulan hasil penelitian ini akan berimplikasi pada individu yang memiliki financial literacy tinggi harus diikuti dengan behavioral intention keuangan yang baik agar pengelolaan keuangannya 
akan semakin cermat.

Hal yang belum diuji dan merupakan keterbatasan dalam penelitian ini adalah peran financial experience sebagai mediasi hubungan financial literacy dan financial management behavior. Peneliti selanjutnya diharapkan dapat meguji model tersebut. Selain itu kontribusi literasi, financial experience dan behavioral intention dalam mempengaruhi perilaku pengelolaan masih sebesar 51 persen. Hal ini menjadi celah penelitian ini serta merupakan peluang bagi peneliti selanjutnya untuk memasukkan variabel lain yang ditenggarai mempengaruhi financial management behavior, seperti sikap keuangan, locus of control dan lainnya, sehingga model yang dihasilkan lebih komprehensif.

\section{REFERENSI}

Ajzen (1991) "The Theory of Planned Behavior Organizational Behavior and Human Decision Processes," Organizational Behavior and Human Decision Processes, 50(2), hal. 179-211.

Arganata dan Lutfi (2019) "Pengaruh Niat Berperilaku, Kecerdasan Spiritual dan Literasi Keuangan terhadap Pengelolaan Keuangan Keluarga,” 34(34), hal. 143-160.

Arianti, Baiq Fitri dan Azzahra , Khoirunnisa (2020) "Faktor - Faktor yang Mempengaruhi Literasi Keuangan: Studi Kasus UMKM Kota Tangerang Selatan”, Jurnal Manajemen dan Keuangan, 9(2), hal. 156-171.

Brilianti, T. dan Lutfi, L. (2020) "Pengaruh Pendapatan, Pengalaman Keuangan dan Pengetahuan Keuangan terhadap Perilaku Keuangan Keluarga di Kota Madiun," Journal of Business and Banking, 9(2), hal. 197.

Chen dan Volpe (1998) "An Analysis of Personal Financial Literacy Among College Students," Chinese Journal of Lasers, 7(2), hal. 107-128.

Ida dan Dwinta, C. (2010) "Pengaruh Locus Of Control, Financial Knowledge, Income terhadap Financial Management Behavior," Jurnal Bisnis Dan Akuntansi, 12(3), hal. 131-144.

Iramani, Rr. dan Lutfi, L. (2021) "An Integrated Model of Financial Well-Being: The Role of Financial Behavior," Accounting, 7(3), hal. 691-700.

Kholilah, N. Al dan Iramani, Rr. (2013) "Studi Financial Management Behavior pada Masyarakat Surabaya," Journal of Business and Banking, 3(1), hal. 69.

Lusardi dan Tufano (2009) "Debt Literacy, Financial Experiences, and Overindebtedness," Journal of Pension Economics \& Finance, 14(4), hal. 332-368.

Mien, N. dan Thao, T. P. (2015) "Factors Affecting Personal Financial Management Behaviors: Evidence from Vietnam," Business,Economics, Finance and Social Sciences.

Panggabean, F. Y. dan Dalimunte (2018) "Analisis Literasi Keuangan terhadap Keberlangsungan Usaha Kuliner Kota Medan,” Jurnal Manajemen dan Keuangan, 7(2), hal. 139.

Purwidianti, W. an Mudjiyanti, R. (2016) "Analisis Pengaruh Pengalaman Keuangan dan Tingkat Pendapatan terhadap Perilaku Keuangan Keluarga di Kecamatan Purwokerto Timur," Benefit: Jurnal Manajemen dan Bisnis, 1(2), hal. 141.

Yulianti, N. dan Silvy, M. (2013) "Sikap Pengelola Keuangan dan Perilaku Perencanaan Investasi Keluarga di Surabaya," Journal of Business and Banking, 3(1), hal. 57-68. 